\title{
表面実装技術とプリント配線板一プロセス技術
}

\author{
大貫 秀文*，馬庭＼cjkstart亮*
}

\section{Production Technologies of Printed Wiring Boards for Surface Mount Technology.}

Hidebumi OHNUKI * and Ryo MANIWA *



* Engineering Department, Printed Wiring Board Division, NEC Corporation (1120, Shimokuzawa, Sagamihara-shi, Kanagawa ken 229)

\section{1.はじめに}

今日の電子機器の製造に不可欠なのがプリント配 線板 (以下 PWB ) で, 半導体デバイスと共に特に重 要な電子部品として業界に認知されるようになって きた。過去の技術革新の歴史において 4 〜 年間の 技術イノベーションは大胆に展開され，今日一世を 風㦄している表面実装技術（以下 SMT）（図 1 ）を 代表とした最先端技術が, 半導体デバイスの技術革 新と符合する動きを示し, 電子機器の装置性能, 信 頼性，経済性を大幅に向上させたと言える。

PWBの設計技術，製造技術を核とした八イテク化， コンピュータ化を最大限に活用した省力化, 高速化 志向は, 産業用 PWB の技術のみならず民生用 PWB の技術イノベーションにも相当なインパクトを与え ている。このインパクトは, 材料技術, 製造設備, 生産管理, 品質保証管理, 環境保全技術等々八具体

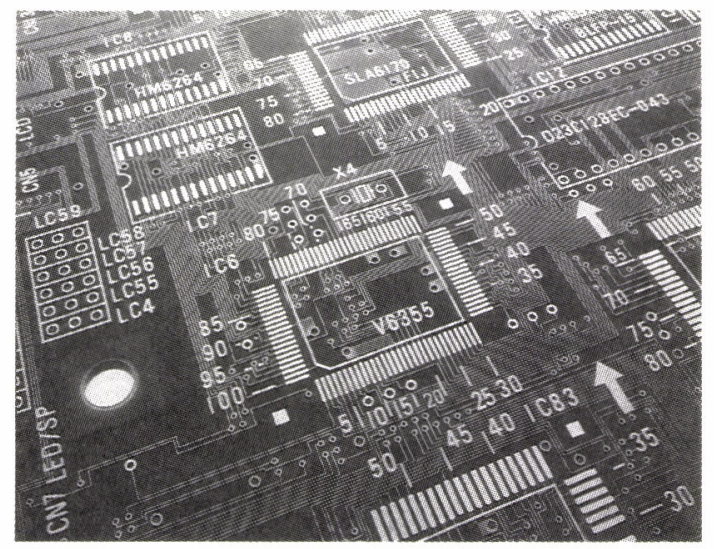

図 1 . 高密度・多層SMTプリント配線板
的に展開されている。

以下，PWBの製造プロセス技術が置かれている環 境と展望を紹介する。

\section{2. にCパッケージからのインパフト}

PWB のプロセス技術に直接インパクトを与える 1 つの要因は，実装するIC パッケージの動向である。

例えばパソコンなどの電子機器を解体すると, 操 作用キーやフレーム, 電子パッケージ等々に分解さ れ，このうち PWBの片面や両面にたくさんの IC ・ LSI，抵抗，コンデンサ等を載せて PWB パッケージ と称して電子頭脳を構成していることは, 周知の通 りである。このように PWBの技術にインパクトを与 えてきているのは，PWBに載せるデバイス，とりわ けICパッケージの動向が最も重要で, 直接 PWBの 設計や製造技術に大きな影響を与えている。

代表的な ICパッケージの物理的特性を比較したの が図 2 である。

DIP IC に較べ，SOP IC は面積で約 $1 / 2$, 高さ で約 $2 / 5$, 重さで約 $1 / 6$ と非常にコンパクトに 収納されている点が電子機器の設計技術者に好感が もたれ, これが電子機器の軽薄短小化への牽引となっ て具現化している。とりわけ PWB 設計と大きく関係 のある IC パッケージの面積が $1 / 2$ となれば, そこ から引き出すリード端子は細く, 高密度化へと推移 するのが当然であり, 必然的に従来にないパッケー ジ設計, すなわちピッチ間の短縮や四方向リード引 き出しなど，平面的，立体的な活用を最大限に行い, むだを省いた ICパッケージの出現となる。今日表面 
実装部品（以下 SMD）の占有率は，33\%位といわれ ており, 今後 2 年後には DIP IC との占有率が大きく 逆転し，54\%を越す占有率となる統計報告 ${ }^{1}{ }^{1}$ が図 3 で ある。

このように SMD の電子機器への浸透は, 経済的, 信頼性的に，工業レベルとして十分認められている ことにほかならない。言い換えると，今後とも加速 度的に普及することが予測でき，PWBにとって SMT が避けて通れない最重要課題と言っても言い過ぎで

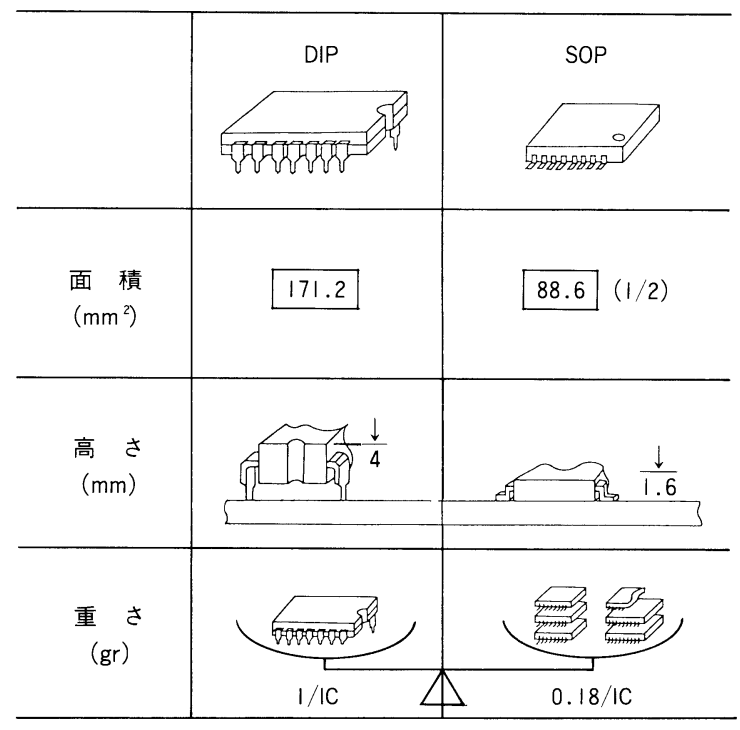

図 2.DIPとSOPの比較

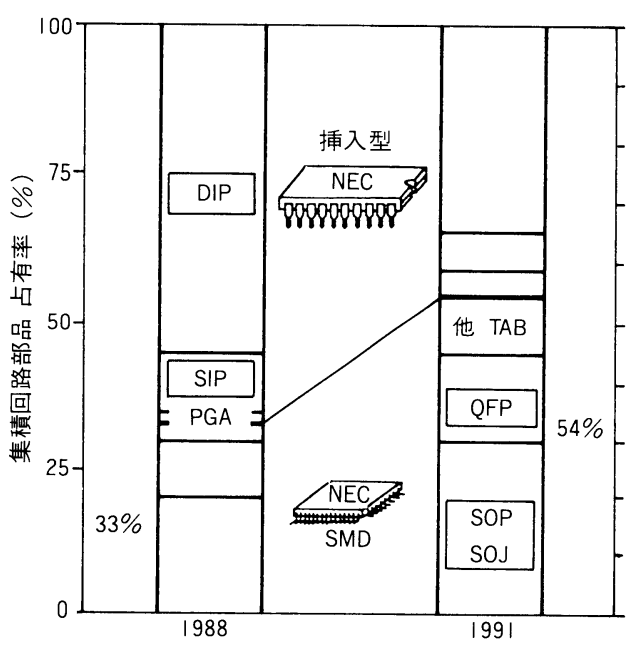

図 3.SMT比率(部品動向)
はないと考える。

IC パッケージの形状変遷は, 産業用 PWB, 民生 用 PWB など区別なく影響を与えているのが現実であ る。そして，SMT 技術は単に PWB の設計，製造， 検査技術のみにとどまらず，部品実装やはんだ付け 技術などの総合技術の集大成化が重要で，この大き なシステムが構築されて初めて生産・販売・顧客 (ユー ザ）間の流れがスムーズに進むものと確信している。

一方 SMT が軽薄短小ばかりを求めてはおらず，超 大型コンピュータを代表とする PWB 分野においては, PWB をシステムの一部として取り込んでおり，PWB 技術としては性能優先の技術開発オリエンテッドな 動きが避けられない。

いずれにせよ産業用 PWB や民生用 PWB は，それ ぞれの求める製品の機能追及から IC パッケージの影 響をダイレクトに受けて，今後共大きく技術変遷し ていくことは確実と言える。

\section{3.製品設計からのインパフト}

PWB プロセス技術にインパクトを与える第 2 の要 因は, 電子機器の動向である。電子機器の高性能化, 高集積化，軽薄短小化の要望は，PWBにとって必然 的に高密度配線化，あるいは立体構成の最大限の活 用へとシフトせざるを得なくなる。

図 4 は，平面実装と多層化を 2 次元に区分し，現 状の PWB 製品技術レベルが今後どのように推移して いくかを予測したものである。

筆者の予測では，OA，VTRなどの領域において は，3本以上の高密度パターン配線に加えて，4 層〜 8 層化へシフトし，板厚も従来 $1.6 \mathrm{~mm}$ 厚の既成概念を 破って薄板化へと推移すると考えている。また，コ ンピュータの領域においては, 超高多層 PWBでの対 応が避けて通れず， $100 \mu \mathrm{m}$ 割る 5 本回路パターン設 計の量産化へと進むであろう。

図 5 は, コンピュータにおける PWB 技術の推移 ${ }^{2)}$ を示すもので，層数は高多層化へと進み，穴径・回 路幅はより一層細くなるため，これに関する設計技 術はますます複雑化を呈することになる。

以上超大型コンピュータとVTR やパソコンなどで は，技術開発や量産ラインの形態が大きく異なり， 電子交換や $\mathrm{OA}$ 機器などの中間技術帯を含めると, 


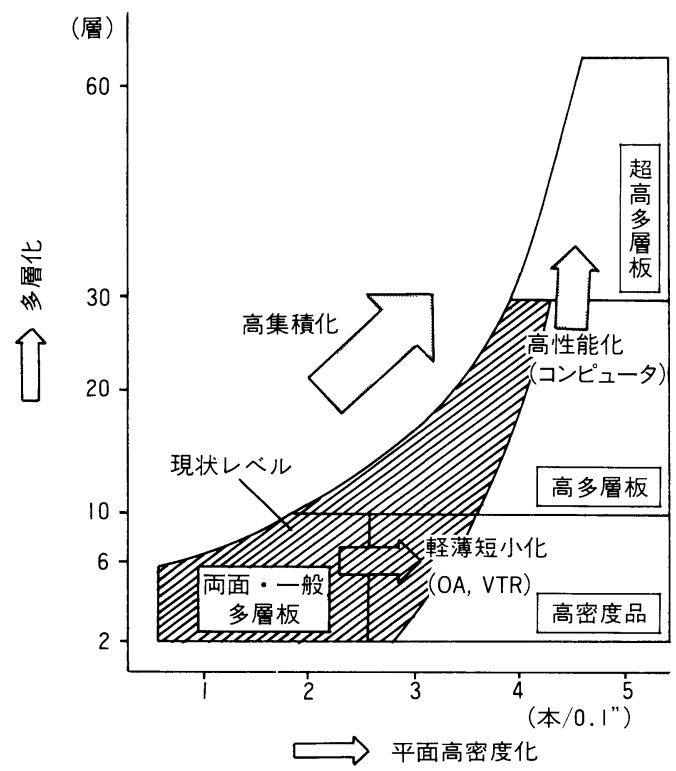

図 4 . 製品の区分

多極分化の様相をいっそう明確に示していくと思わ れる。

図 6 は，これらの背景をもとにPWB の製造設計動 向を予測したもので，概念的にイメージの把握がで きると期待する。 5 〜 年前まではごく一部のコン ピュータメーカを主体に開発実用化が進められてい た技術項目，例えば小径ランドレスやバイアホール などが，産業用 PWBのみならず，民生用 PWBにも 適用され始めている。

一方 PWB の層数アップと小径化に加え，SMT の 出現によるパッド幅やピッチ間設計の新たな対応と, ソルダレジスト（SR）の逃げ設計が重要となってき た。

表 1 は, 現在量産化されている SMT 用 PWB 設計 基準で，ある代表例を示す。このなかで最も厳しい

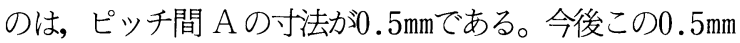
ピッチの SMD の急増に伴い, 材料の寸法安定化, 製 造・検査，はんだ付け技術確立が急務で，一部試作 評価を開始しているとされる $0.4 \mathrm{~mm}$ や $0.3 \mathrm{~mm}$ ピッチの $\mathrm{SMD}$ 技術に，早く対応することが必要である。

\section{PWB プロセス技術}

上記のごとくカスタム部品である PWB 市場は IC パッケージングや電子機器の影響を短期間にうける。

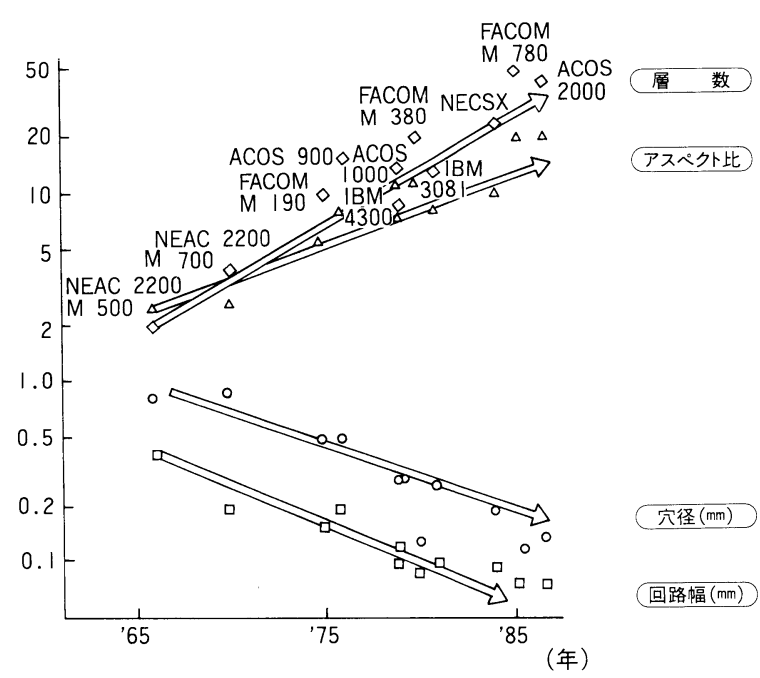

図 5 . コンピュータにおけるPWB技術の推移

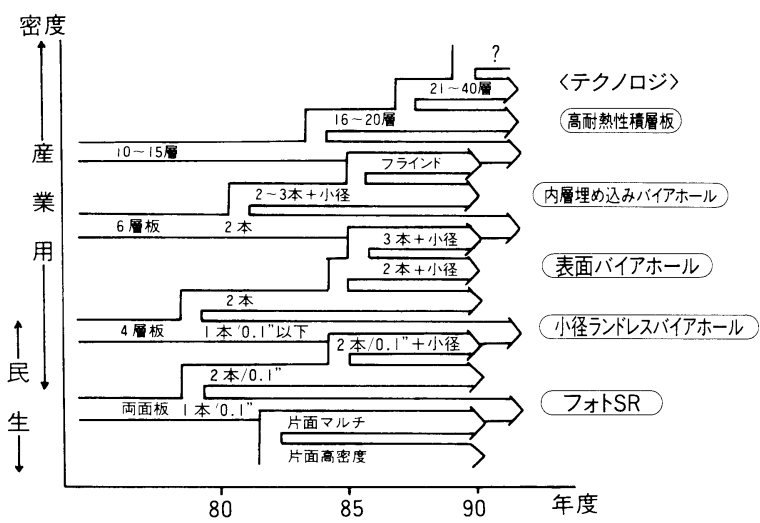

図 6.プリント配線板製品設計動向

この状況下での PWB 製造プロセスは，従来各種の方 法が提案され実用化されてきており，今日その主流 となすところは，サブトラクティブ法として銅スルー ホール PWB，はんだめっきPWB，アディティブ法 としてフルアディティブ PWBの 3 工法が主流を示し ていると思われる。特に銅スルーホール PWB は，通 信産業用 PWB として信頼性評価を昭和 40 年当初より 繰り返し行われ，この実績により実用化されたソル ダレジスト付き高密度銅スルーホール技術が SMOBC （Solder Mask Over Bare Copper）と称され，技術・ 品質などが世界的に認められてきた。

さらに一部溶融はんだコート法（HAL）などの応 
表 1.SMT用PWB設計基準(パッド\&SR)

\begin{tabular}{|c|c|c|c|c|c|c|c|}
\hline \multirow[b]{2}{*}{ 種 類 } & \multirow[b]{2}{*}{ ピン数 } & \multicolumn{3}{|c|}{ パッド } & \multicolumn{2}{|c|}{$\mathrm{S} \quad \mathrm{R}$} & \multirow[b]{2}{*}{ パターン配置図 } \\
\hline & & $\begin{array}{c}\text { ピッチ } \\
\text { A }\end{array}$ & $\begin{array}{l}\text { 幅 } \\
\text { B }\end{array}$ & $\begin{array}{c}\text { 間 隙 } \\
\mathrm{C}\end{array}$ & $\begin{array}{l}\text { 幅 } \\
\mathrm{D}\end{array}$ & $\begin{array}{l}\text { クリアラ } \\
\text { ンス } \quad \mathrm{E}\end{array}$ & \\
\hline \multirow{2}{*}{$\begin{array}{c}\text { SOP } \\
(\mathrm{PLCC})\end{array}$} & \multirow{2}{*}{$\begin{array}{c}8 \\
1 \\
28\end{array}$} & \multirow{2}{*}{1.27} & $\begin{array}{c}0.5 \\
j \\
0.6\end{array}$ & $\begin{array}{l}0.77 \\
\int^{\prime} \\
0.67\end{array}$ & $\begin{array}{c}0.37 \\
\quad \\
0.57\end{array}$ & $\begin{array}{c}0.1 \\
\text { s } \\
0.15\end{array}$ & \multirow{2}{*}{$\underbrace{\mathrm{B}_{1}^{\mathrm{B}}}_{\mathrm{A}}$} \\
\hline & & & $\begin{array}{c}0.6 \\
j \\
0.7\end{array}$ & $\begin{array}{c}0.67 \\
\text { J } \\
0.57\end{array}$ & $\begin{array}{c}0.27 \\
\int_{0.47}\end{array}$ & $\begin{array}{c}0.1 \\
j \\
0.15\end{array}$ & \\
\hline \multirow{5}{*}{ QFP } & 64 & 1.0 & 0.6 & 0.4 & 0.2 & 0.135 & \multirow{5}{*}{$\mathrm{B}_{+} \mathrm{C}_{4} \mathrm{D}_{4}$} \\
\hline & 80 & 0.8 & 0.5 & 0.3 & 0.13 & 0.085 & \\
\hline & 100 & 0.65 & 0.35 & 0.3 & 0.13 & 0.085 & \\
\hline & 48 & 0.5 & 0.25 & 0.25 & 0.1 & 0.075 & \\
\hline & & 0.4 & 0.22 & 0.18 & 0.08 & 0.05 & \\
\hline
\end{tabular}

用例があるが，SMT 技術の急激な普及により， $\mathrm{SMOBC}$ の特性が大きくクローズアップされてきてい る。その特徵は, SMOBC が高密度高精度配線にす ぐれており，SR の形成が容易で，SMT のはんだ付 け品質に信頼性向上が伴ったことに裏付けされよう。

以下，PWB のプロセス技術の今後の展望をまとめ てみた。

\section{5. 基板材料，多層化技術}

基板材料の特性は，PWB の品質を左右するため, 非常に重要である一方，PWB の大部分のコストをも 決めるファク夕として技術的，経済的に重要項目で ある。民生用 PWB としては，紙フェノール材が主 流であるが，コンポジット材（CEM 材）の適用がこ こ数年急増し, 今後もその特性を最大限活活用し増 加するだろう。さらに一部がラスエポキシ材（FR一 4 など）の適用も進みつつあり，例えば VTR や八イ ビジョン TV などの民生用 PWB のマーケットトレ ンド次第では増産による期待ができょう。他方，産 業用 PWB は，両面板，4層板の比重が大きく，ガラ スエポキシ（FR-4 など）が主流である。また超高 多層などでは，ポリイミド材がかなり使用されてき た。一部電気特性の対応としてテフロン材などが実 用化に供されている。

今後の基板材料の特徵的動向としては，民生用 PWB
では SMT 化の大幅採用による薄板 4 層化， 6 層化が 浸透し始め，これに伴い FR - 4 の普及が顕著となろ うし，産業用の高多層（20層以下）では，主流のポ

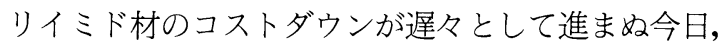
これを解決するため，FR－5 またはそれに相当する ガラス転移点（ $\mathrm{Tg} ）$ が $160 \sim 180^{\circ} \mathrm{C}$ と高め側の材料適 用も拡大するだろう。

いずれにせよ材料品質は世界的に認められていて も, 低コスト化の推進が遅れている現在, 従来の既 成的考元方では国際競争力に勝てぬため，大幅な材 料技術改善を期待するところである。

多層化技術は，減圧，低圧プレス（真空プレス） が材料メーカ，エッチングメーカ共にほぼ普及し， 多層化成形技術の向上が大幅に望め，かつ反り減少 や寸法安定化が期待できる。今後特に技術的に改善 せねばなら颀目として，小径化に対する内層銅䈃 ハローイング性の改善（ハローレスPWB），内層銅 箔 $35 \mu \mathrm{m}$ 化（一部 $18 \mu \mathrm{m}$ 化の出現）に伴うデスミアの内 層接続信頼性技術確立，高密度配線化化伴う外層銅 箔 $12 \mu \mathrm{m} （ 1$ 部 $9 \mu \mathrm{m} ）$ の安定生産などの，技術的ハー ドルを超える必要が急務と痛感している。

図 7 は，薄板 4 層 PWB の断面写真の実用化例。図 8 は, 表面バイアホール（SVH） PWB の断面写真 の実用化例。図 9 は,内層バイアホール（IVH） PWB を実用化した超高多層 PWBであり，今後ますますこ 
のような PWBの総合技術力が求められた製品が増大 するものと予測している。

\section{6. 穴あけ, 機械加工技術}

$\mathrm{SMT}$ の普及に伴う多層化へのシフトは，後述する 検査工程と共に穴あけ工程に大きなインパクトを与 えてきた。

すなおち SMT 一実装配線密度の増一穴数の増一配 線領域確保のため, 小径スルーホール化・微細パッ ド化ＩVH，SVHによる多層化など一連技術変遷 に伴い, 穴あけ工程は, 複雑な穴あけ条件の設定と 共に生産効率をいかに向上させるか, すなわち内層 板や薄板 PWBの穴あけにおいて重ね枚数のアップ, 穴あけスピードのアップ, ドリルビット増大に伴う ドリルチェンジ時間の短縮と, かなり技術開発項目 が付きまとうことが確実である。

一方超高多層 PWB に関しては, 板厚が厚く穴径が 小径化するため, 高アスペクトのスルーホールとな り, 生産効率よりも品質や信頼性の局面がどちらか

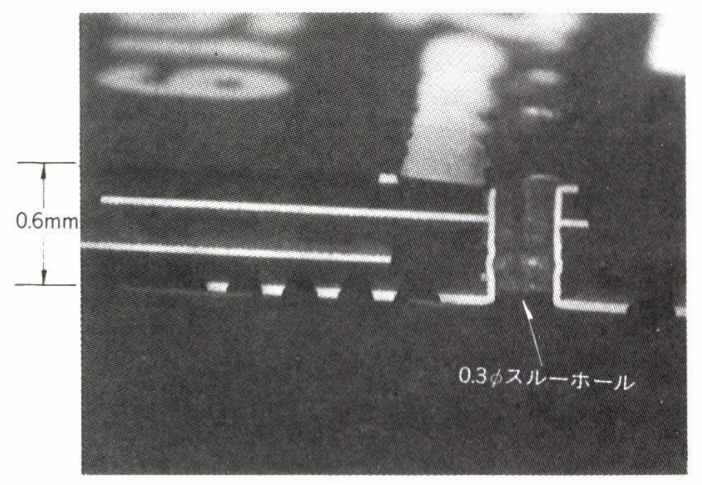

図 7 . 薄板 4 層板の断面写真

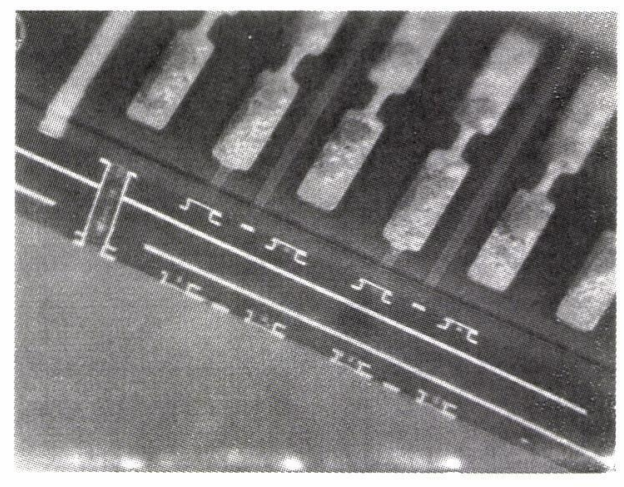

図 8、表面バイアホール(SVH)多層PWBの断面写真
と言えば重要視されよう。いずれにせよ $\mathrm{CO}_{2}$ レーザ などの特殊穴あけ方式などもアメリカで開発実用化 されているが，当面はドリルビットによる穴あけの 経済性には今のところ勝るものはないため，信頼性 と経済性の追求が重要ポイントで, 省人化, すなわ ち CAM， CIMS 化の技術導入がますます望まれる ところである。

外形加工は, パンチング， CNCルータなどの従来 技術が主流で，これに付加してVカットやミシン目 などが追加され，個別対応化が求められる反面，量 産化と変機種変量の両極端化が進み, 省力化対応の 工夫が一層望まれる。

\section{7. めつき，表面処理技術}

サブトラクティブ法によるめつき技術は, 無電解 めっき, 電気めっきの組み合わせで特に基本工法に 大きな革新はないが，材料組成的においてはPWBを 活性化処理し，ダイレクトに電気銅めつき3゙する無電

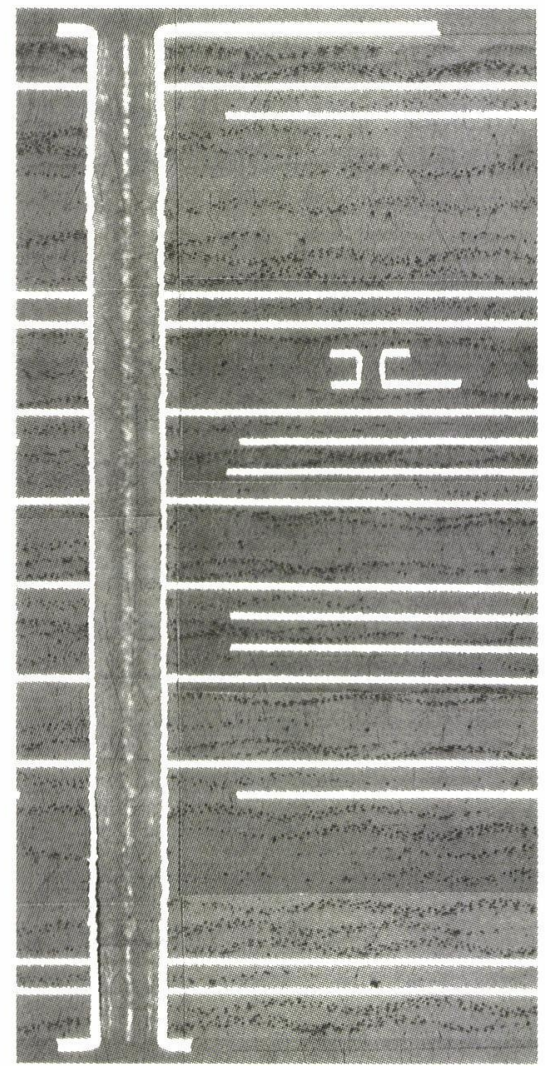

図 9.内層バイアホール(IVH)の超高多層PWBの 断面写真 
解銅めっき工程の合理化が最近開発されたり, 酸性 銅めっきの物性向上に伴い, 硫酸銅めっきが現在主 流になりつつあると言ってもよいだろう。

他に各種の技術があるが，今日の技術的課題は， 薄板, または高板厚 PWB と小径スルーホールに対す る基板材料技術，穴あけ技術と連携したデスミア処 理技術の安定化確立が急務とされている。特にプラ ズマや過マンガン酸などのデスミア処理後の無電解 めつきの付きまわり性は，めっき技術のみにとどま らず前工程までさかのぼった技術改善が時として求 められるケースがある。

SMOBC 用 PWB の表面処理方法は, 銅表面の酸化 防止処理としてのプリフラックスと HAL 工法とに大 別できよう。SMT 化の進展に伴い, 従来 1 回の熱履 歴のみの保証から複数回の特性要求へと変わり, か つフローはんだ付けのみの過去の状況から，赤外線， VPS などのリフローソルダリング工法へと, ここ数 年はんだ付け技術が大幅に変更されてきた。この 変更に伴い, 銅スルーホール PWB の銅表面の仕上げ 処理として, 複数回のリフローソルダリングに対し て良好なはんだ付け性を保証するために，耐熱性を 有する表面処理方法 ${ }^{4)}$ が開発された。図 10 は, 開発事 例で従来に較べ相当改善されていることがわかる。 今後は, 環境改善と耐熱性を有した水溶性プリフラッ クスの開発実用化が進みつつある。

一方，HAL の方式では表面処理用の耐熱フラック スの開発は当面要求されていないが，SMT の四方向 リードパッドのはんだ不均一性, 小径スルーホール のはんだ詰まりによる盛り上がりなど，従来技術に ない項目の技術改良がますます求められることは， 明白の事実と受けとめている。さらに一部電子機器 においては, 部分的に接点機能を PWBに求める技術 要求があることや，はんだリフローの多重回繰り返 しニーズの台頭や，はんだアッセンブリ後の PWB 洗 浄削除による環境保全対策などを背景とした，無電 解ニッケル・金めっきの組み合わせにより，表面処 理を代替する動きがあり，今後の技術確立が急がれ る。

\section{8. 回路形成, $S R$ 技術}

民生用 PWB は，主としてUV 型インキによるス

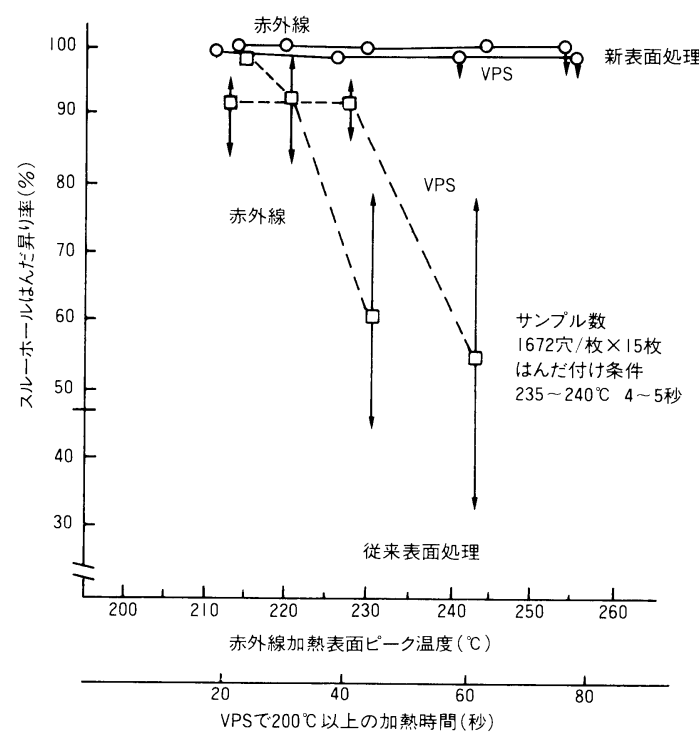

図10．新表面処理を用いたはんだ付け特性

クリーン印刷法が主流で, 今日かなりの高精度化対 応までをカバーしていると推定される。一方, 産業 用 PWB は，両面，多層 PWBが多く，かつ高精度， 高密度化の進展が早かったために，回路形成として ドライフィルムが普及し，今日ほとんどが写真法へ と切り換わったものと思われる。いずれにせよドラ イフィルムは PWB 業界の一大革命であり, PWBの 求めていた高精度, 高密度かつ経済性の波にうまく 乗ってきたと明言できよう。ただ，数年前から世界 的環境問題として顕在化したため, 塩素系有機溶剤 のドライフィルムからアルカリ可溶型のドライフィ ルムへと切り換わり,今後 $2 \sim 3$ 年内で急ピッチに進 むことは確実である。SR技術は，熱硬化型エポキシ 樹脂からフォト SR 化へと切り換わり，特に液状フォ トSR の普及は，SMTの拡大とほぼ同じくして歩ん できたと言ってよい。

従来, SMT の代表的な QFP ( Quad Flat Package ）では，端子間ピッチが0.65mm上であっ たが，最近は0.5m片ッチの QFP が使用されはじめ, さらに $0.4 \mathrm{~mm}, 0.3 \mathrm{~mm}$ と狭いピッチのものまで検討さ れている。このように SMT の端子間ピッチが狭くな ると, はんだ付け時のブリッジ防止の点から, 接続 パッド間に SR を印刷することが不可欠となってきて いる。このため, 最近は細い SR ラインを形成する技 術と, 高精度な合わせ技術が要求されてきている。 
図11は，QFP端子間ピッチに対するパッド間吵， $\mathrm{SR}$ ライン幅，SRクリアランスの設計基準を示した。

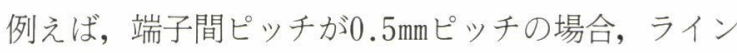

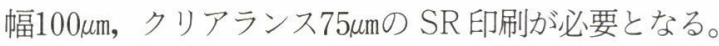
図12は，0.5mmピッチのパッド間に SR を印刷した製 品例である。

当社の例でいうと,ほぼ70\%以上のPWBが液状フォ ト SR で，数年後にはほぼ完全に切り換わると見込ん でいる。当面のフォト SR 技術動向は, 量産化のため に両面同時露光技術，インキ塗布技術（例えばスプ レー方式）などの開発が列記できよう。

今後，回路形成技術で特筆すべきことは，SMTの 普及拡大に伴(, サブランド5),6)付きランドレススルー ホール化 (図13), ピン間 5 本パターン7) (図14）な どが高密度設計に適しており (図15), 原画作成の TAT 短縮と併せて普及するものと推察される。今日この 方法としては, 穴埋めフォト法あるいは, ED 法, TDN 法などが提案され，一部実用化されている。

今後は, どの技術が最も信頼性が高く，経済的で あるかの洗礼を受けるか, 長年続いたドライフィル

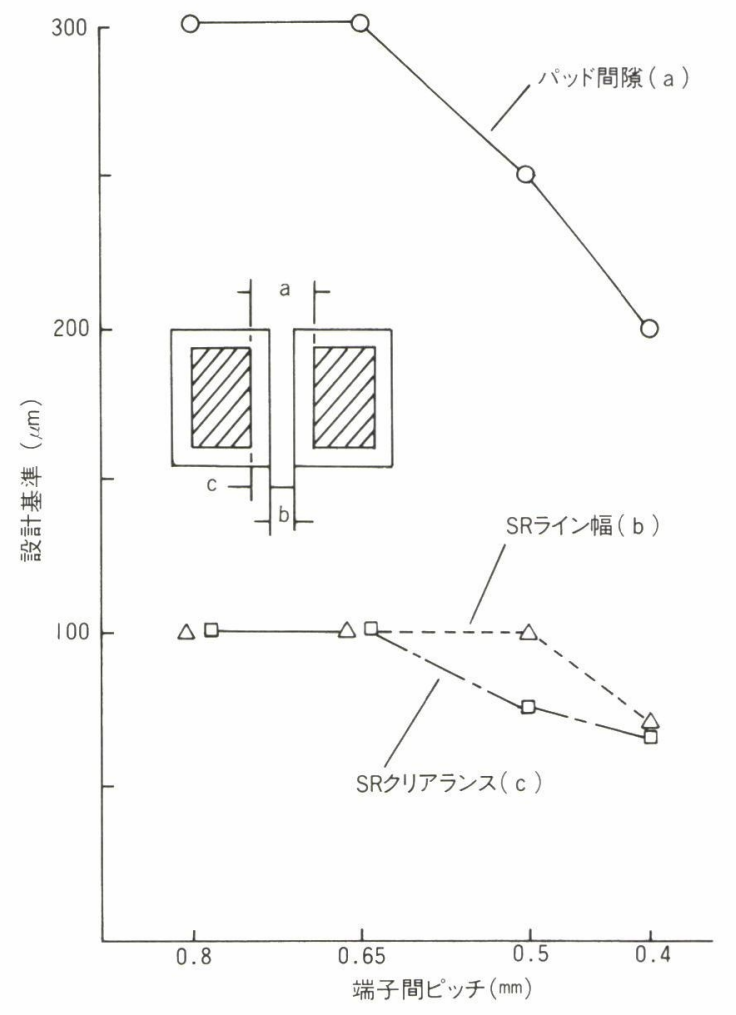

図11.QFP端子間ピッチとSRの設計基準
ムに換わる方式として注目されている。

\section{9. 文字印刷技術}

$\mathrm{SMT}$ の高密度実装の進展により, 部品の認識マー

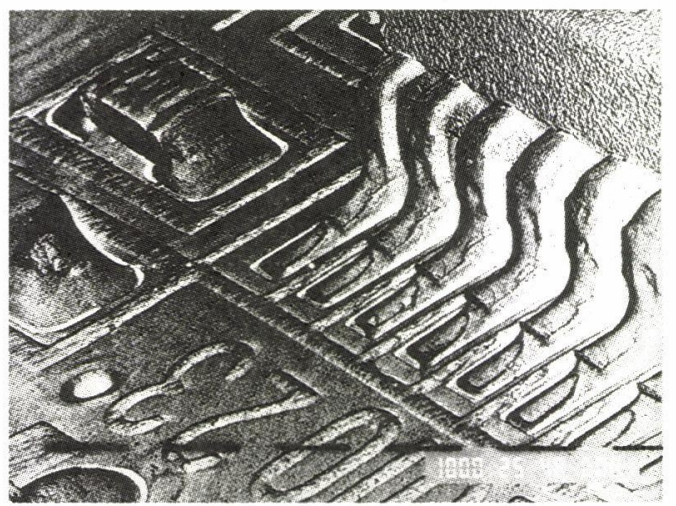

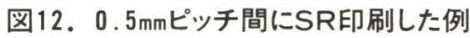

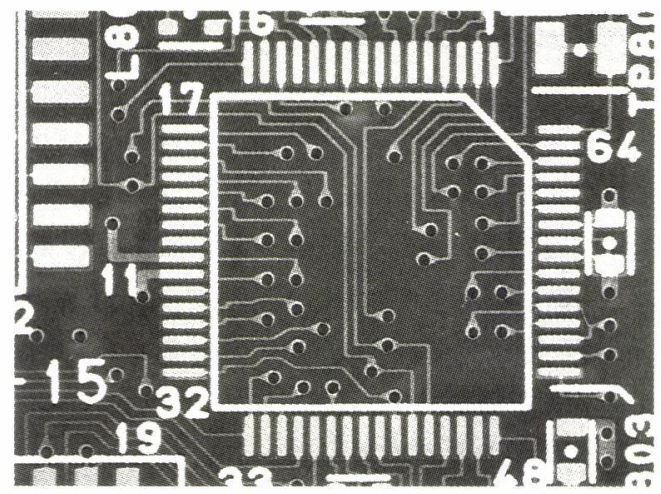

図13.サプランド付きランドレススルーホールPWB

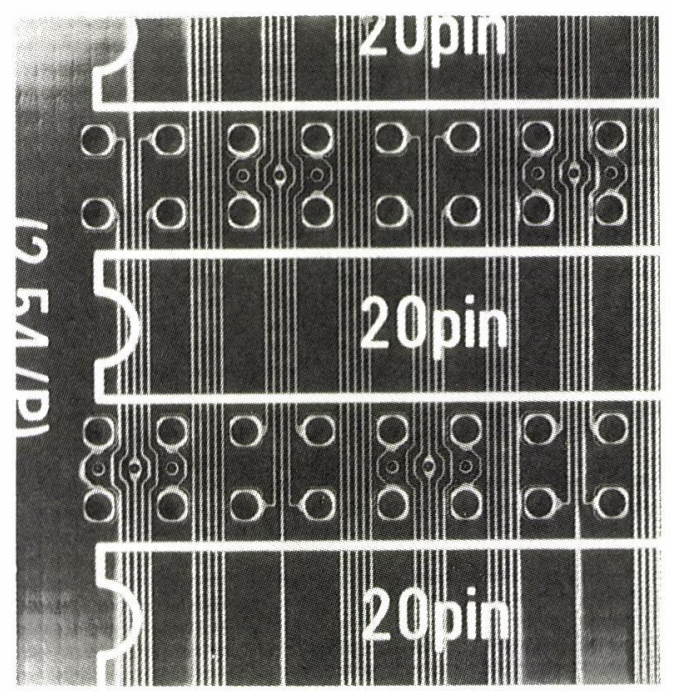

図14.ピン間 5 本回路パターン 
クとしてのマーキングの大きさも小さくすることを 要求されている。従来, マーキング文字は $0.2 \mathrm{~mm}$ の線 幅で高さ $1.5 \mathrm{~mm}$ ものが使われていたが, 部品間のス ペースの制約から，線幅 $0.1 \mathrm{~mm}$ で高さ $1.0 \mathrm{~mm}$ あるいは これ以下のものを印刷することが不可欠となってき ている。当社の例では新たに高精度対応のスクリー ンを使用することにより, 高さ $0.8 \mathrm{~mm}$ のマーキング文 字を可能にした。また, 図16に示すように印刷位置 精度の向上も実現している。

\section{0. 検査技術}

SMT 技術の拡大に伴って，大きなインパクトを受 けたのは検査技術であろう。特に電気検査において は, 従来法に比べパッド幅が細くなったのと, パッ ドピッチ間が $0.5 \mathrm{~mm}$ と幅に縮小したこと, さらに表 裏に配置するケースがあり, 回路形成の位置合わせ

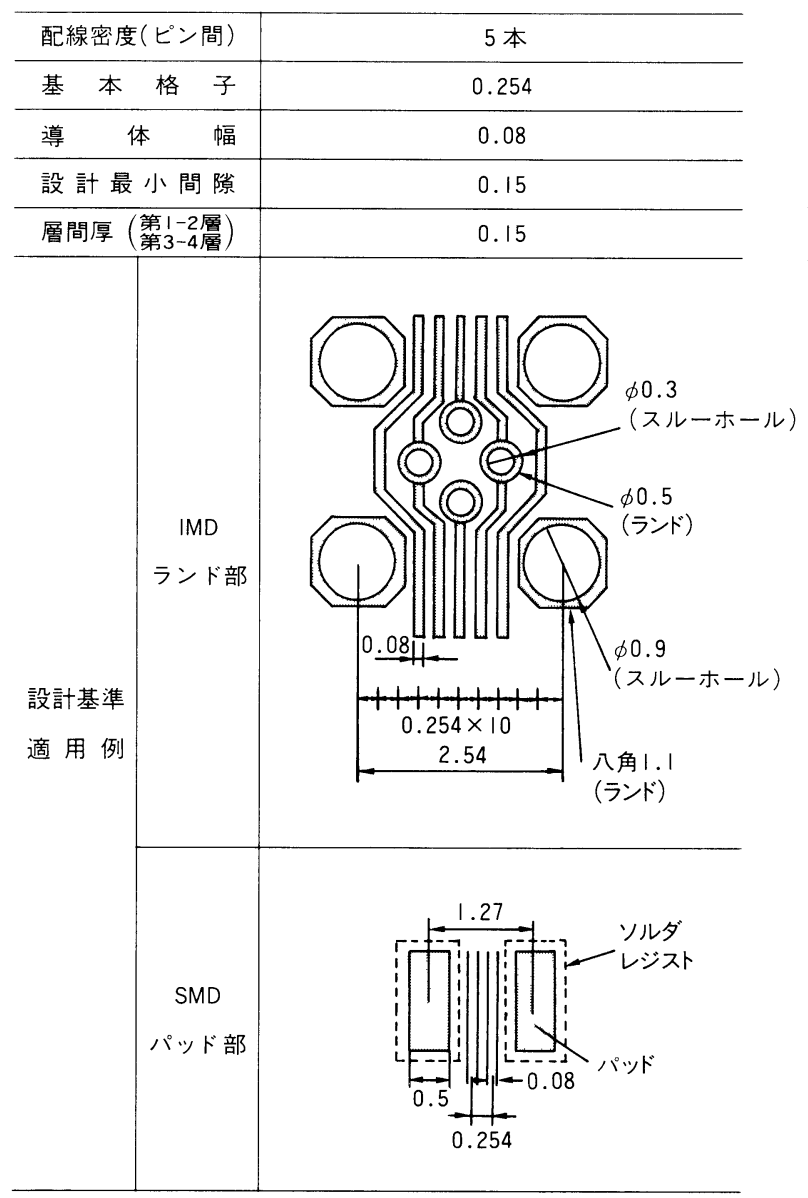

図15. ピン間 5 本の設計基準
精度, SR の印刷精度, 基材の伸縮と検査治具の位置 精度とに不整合が生じ，急激に問題点が噴出したと 言える。最近は，電気検査の導通判定と絶縁判定に 加え, 光学検査機（AOI） が普及してきて, かなり の効果を発揮している。今後, 検査技術面における ソフト，ハードの一層の技術改善が望まれるところ である。

\section{1．生産設備技術動向}

PWB の生産設備動向は, 従来から注目を浴びてい る CAD， CAM，そして CAT 技術があるが，今日 パソコン, VTR などを代表とする量販対応の TAT 短縮とした生産管理システムの構築, それに合理化, 自動化を含んだ CIMS の構築が従前に比べ重要となっ てきたと痛感している。

図17で示すような $\mathrm{CAD}$ システムは, 各種の方式が 提唱され, 大別すると超大型コンピュー夕開発など にみられる大規模なシステム開発用と, OA，パソ コン，VTRなどにみられるコストパフォーマンスと パーソナルユーズに仕分け，いずれにせよ設計技術 者の繁雑業務, 定型業務, 設計 TAT 短縮, 自動配線 率の極限の追求等を改善するため, 今日必ずしも満

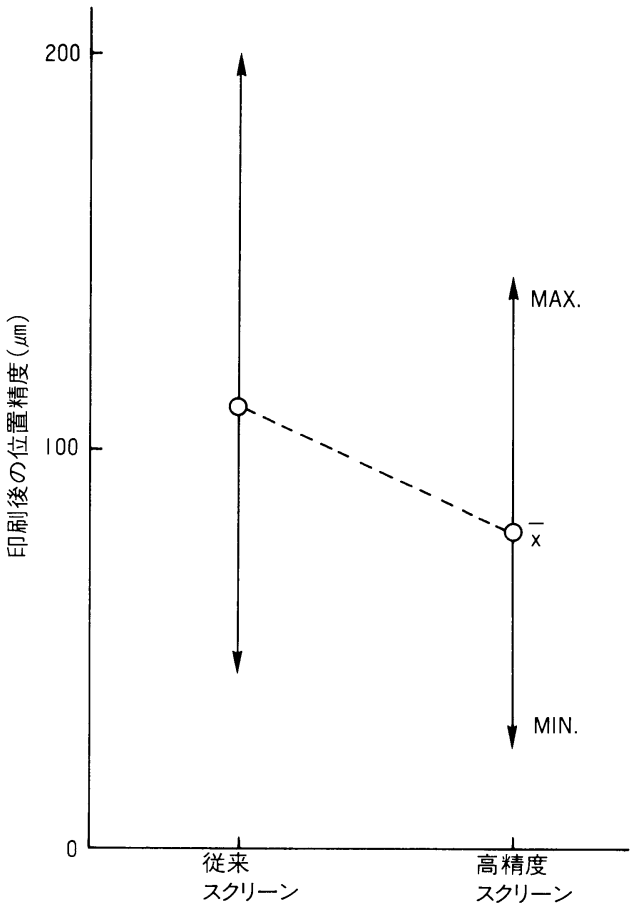

図16. マーキングの印刷位置精度 
足がいってはいないので，今後もますます改善して いくことを期待している。

また，新しい考え方としてデザインインが提唱さ れ，各社仕様をより早く実現するために地方や社内 各工場にデザインセンタを配置し, カスタムユーズ 対応を開始した例もある。

CAM 技術は，省人化を狙いとして開発実用化され ており，穴あけ，めっき，回路形成などに大きな効 果を得ている。図18は, 当社の全自動穴あけシステ 厶 ${ }^{8)}$ で, 従来から問題となっている穴あけデータの自 動読み出し，PWBのロード，アンロードのみならず, TAT 短縮のための穴あけ予約システム (図19), 稼

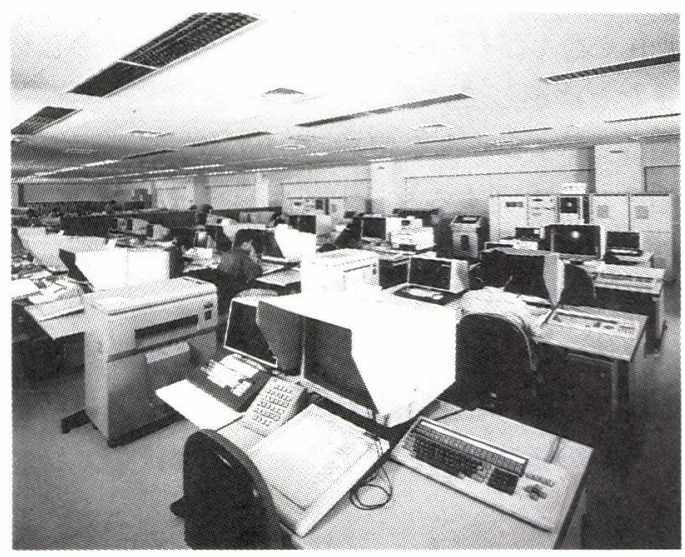

図17.PWBを設計するCADシステム

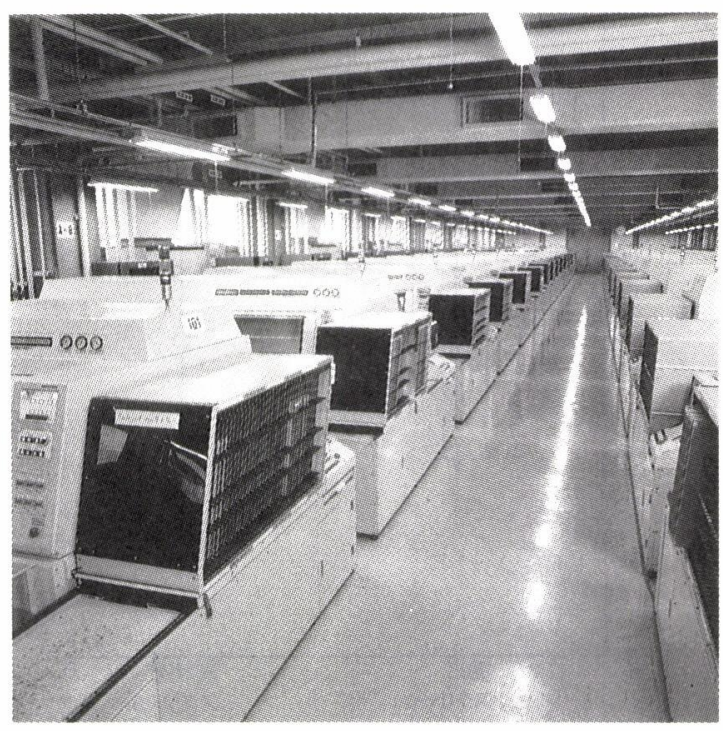

図18. 全自動穴あけシステム
働率調査（図20，，TPM の不良解析（図21）と相当 数の機能を盛り込むことで, 効率化を達成している 実例である。システムの概念図は，図22に示される。 本システムの特徵は, (1) PWB 生産管理システムとリ ンクしていること, (2) 穴あけデータを一元管理し, 各穴あけ機を数台グルーピングして群管理している こと，(3)穴あけ機は現在最も進歩したFA 技術を導 入していること, (4)穴あけ監視システムを用いたTPM 管理をしていること等が記述される。

CAT は前述の検査技術で述べたが，今後は CAD 上 り一元化された自動デー夕活用, 検査品の修正, 補 修技術の改善が望まれる。今後ますます高密度化， 高多層化移行に伴って, 各工程ごとの作り込み品質 保証をする上での CAT 技術は, 重要性を帯びてくる と確信している。

\section{2. おわりに}

以上，昨今の PWB工場は，単にソフト，ハードの

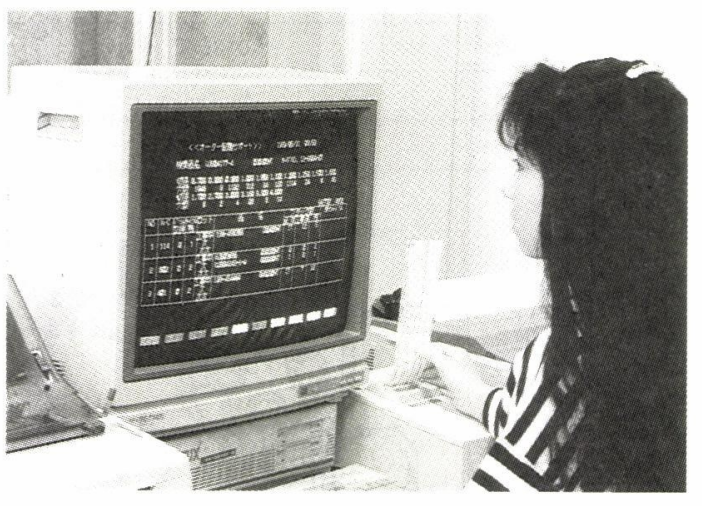

図19.予約システム

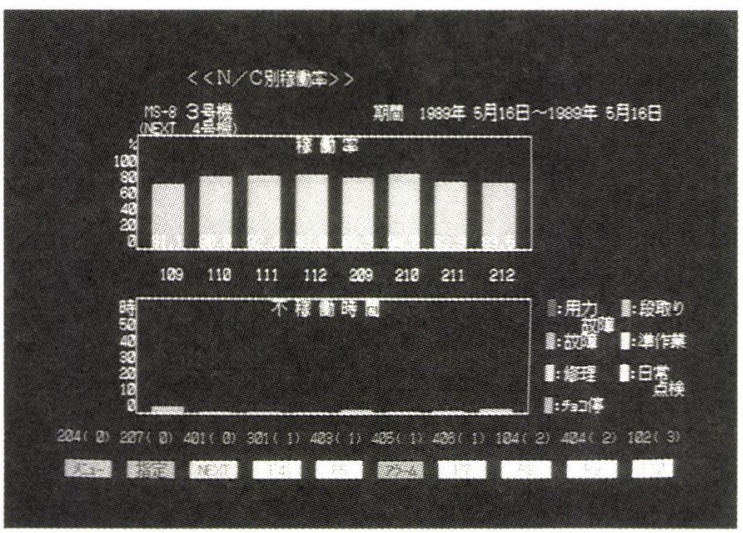

図20。稼働率調査 
物造りのためのコンピュータ活用では満足できるも のではなく, カス夕ム化, 量販化, 変機種変量化, TAT 短縮化，省人化など総合的に設計した体制の構 築が，今後の競争に生き残れるものであると確信し ている。これらのシステムを構築するには，諸資源 （人・物・金・情報）の適正化が重要であることは 言うまでもない。

\section{文献}

1) JPCA 資料，1988年版

2 ) 磯部： NEC 技報, Vol. 38, No.2, p. 151, 1988

3 ) Olin Hunt Technical Paper, NEPCON WEST,1990

4) Noguchi, Hirai, Nakamura et al. : NEC R \& D, No.92, p. 64,1989

5 ) 特許第1082787号
6 ) 商標登録第 87597 号

7 ）桑島，斎藤：NEC 技報，Vol.42, No.8, p. 33, 1989

8 ）大貫, 他：工場管理, Vol. 35, No.6, p. 54, 1989

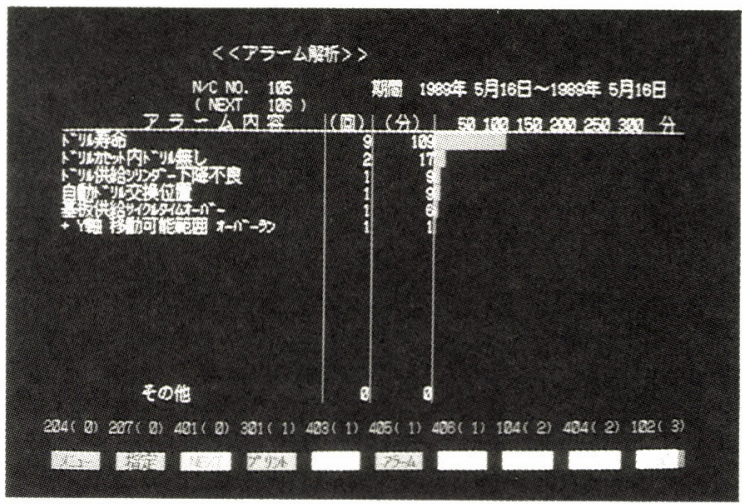

図21。不良解析

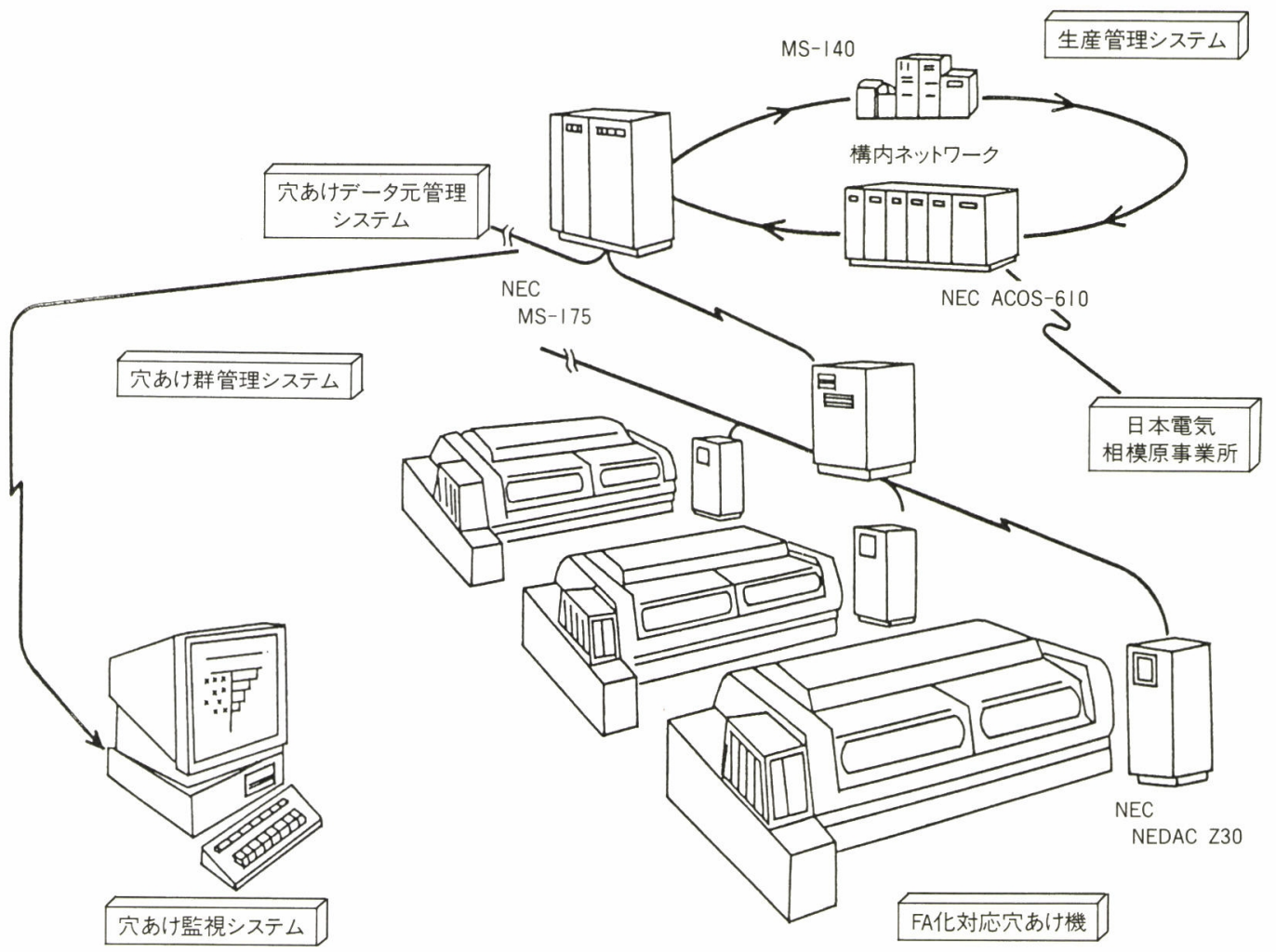

図22.システムの概念図 